\title{
Employee voice and participation: the European perspective
}

Book or Report Section

Accepted Version

Brewster, C., Croucher, R. and Prosser, T. (2019) Employee voice and participation: the European perspective. In: Holland, P., Teicher, J. and Donaghey, J. (eds.) Employee Voice at Work. Work, Organization, and Employment. Springer, pp. 5196. ISBN 9789811328190 doi: https://doi.org/10.1007/978981-13-2820-6 Available at https://centaur.reading.ac.uk/82480/

It is advisable to refer to the publisher's version if you intend to cite from the work. See Guidance on citing.

To link to this article DOI: http://dx.doi.org/10.1007/978-981-13-2820-6

Publisher: Springer

All outputs in CentAUR are protected by Intellectual Property Rights law, including copyright law. Copyright and IPR is retained by the creators or other copyright holders. Terms and conditions for use of this material are defined in the End User Agreement.

\section{www.reading.ac.uk/centaur}

\section{CentAUR}


Central Archive at the University of Reading

Reading's research outputs online 


\title{
Employee voice and participation: the European Perspective
}

\author{
Chris Brewster, Richard Croucher \& Thomas Prosser
}

\section{Introduction: voice and participation in Europe}

Arguably, Europe is at the centre of some of the most fascinating developments in employee voice and participation. Definitions of 'Europe' vary: the term can refer to the 28 states of the European Union (EU), the 32 countries of the European Free Trade Area, which includes, in addition to the EU states, Iceland, Lichtenstein, Norway and Switzerland, the 47 countries in the Council of Europe or the wider geographical definition of 'the Atlantic to the Urals'. Here we refer to the European Free Trade countries and the countries immediately to the east of them. We therefore include the ex-communist countries now bordering Russia, because we recognise the relevance of their model of corporatist employee voice for countries to their West (Upchurch et al, 2015; Croucher, 2016). Although we will note developments in all of these states, our focus will be on the European Union countries and the specific experiments in employee voice and participation there, largely because these are the countries best covered by researchers. We do not discuss Russia, which has increasingly distanced itself from Europe and the USA. It has recently sought to build alliances with other post-Soviet countries through the Eurasian Economic Union which it sees as a potential counterweight to the EU, with an alternative social model.

Europe is significant not just in its own right as a major world trading bloc but as an exemplar for other countries. The colonial legacy of countries like the UK, France, the Netherlands, Spain and Portugal continues to have an impact on HRM practices in other countries (Wood et al, 2016) and experiments on this continent are carefully watched elsewhere. While Germany's colonial presence was less important than that of the other countries listed, its long traditions of economic involvement in Central and Eastern Europe, historic relationship with Turkey and its status as an economic 'high road' powerhouse means its model carries great weight internationally. South Korea's works councils for example were initially modelled on their German equivalents (Croucher and Miles, 2009). 


\section{ADD CHAPTER OUTLINE}

\section{What is distinctive?}

The significance and appropriate forms of employee voice and participation have long been debated at the European level. From the launch of European integration in the 1950s, it was understood that deepening European economic integration necessitated Europe-wide structures for employee voice and participation. Though initial efforts to develop such structures were rather tentative, the launch of the European single market project in the mid-1980s led to more sustained attempts. Such efforts reflected the 'special', sui generis nature of European integration. Unlike regional integration arrangements in other parts of the world, the European project was predicated upon a deepening of integration between member states which, in the sphere of social policy, implied the development of common social policy institutions (Falkner, 1998).

Europe therefore provides a specific context for examining voice and participation. Several factors make its approach to voice and partnership distinctive (Sparrow, Mayrhofer \& Brewster, 2012). These factors originate in European history and the fundamental idea that democratic rights exist in the workplace as well as in society. The result is a number of differentiating elements at the European level: its 'stakeholder' rather than shareholder model; the role of the state; the notion of 'rights' to and in a job; and an acceptance by managers of the value of consultation. There are also very considerable differences not only between European countries but also within the different country groupings that have been proposed and are discussed further below. Even in the 'Nordic' countries, where many features of the European model find their strongest expression, very considerable differences exist between nations (Gooderham et al, 2014). Yet despite this diversity a discernible model exists and although none of its components are unique, the combination makes Europe different. We comment briefly on each component in turn in order to set the scene for the rest of the chapter.

The idea of democratic rights at work and in society. The essential origins of Europe's distinctive set of practices lie in a long history of creating democratic institutions and applying them to industry and society. Europe had a centuries-long history of industrial activity and wage labour even before the development of capitalism, giving rise even then to a dense body of trading and employee institutions. The more immediate origins of the distinctive elements we identified above lie in the development of strong workers' movements during industrialisation in the nineteenth century. These built and exchanged well-articulated 
ideologies of industrial democracy, workers' control of industry and social reform. In all Continental European countries, trade unionism developed from workers' movements from below which were steered and shaped either by social democratic parties or by more radical activists. British history showed the reverse tendency: the Labour Party was formed by trade unions and stamped by their more pragmatic ideologies. All of these parties, both the British and Continental European versions, sought to reform society in more egalitarian and inclusive directions. They encouraged, brokered and participated in national and then international social settlements between capital and labour throughout the twentieth century and down to the present. They were integrated into European countries' polities, became parties of government and then provided strong and even essential legal support for trade unionism and worker voice more widely (Western, 2000). Their reforms were generally accepted by other political parties as they were seen as providing social and industrial stability, and during the Cold War as building a bulwark against Communism. The social settlement was underpinned by the prosperity and full employment of the post-war boom years: the Trente Glorieuses. This unique 'social contract' weakened as the memory of war receded and was called into question by a resurgence of conservative politics and neo-liberal economics after the 1970s oil price shock. The sheer strength of the challenge meant that social democratic parties began to abandon much of their pro-worker agenda even before the collapse of Communism removed the failed alternative model from the political landscape. The post-1945 settlement was then largely dismantled during the last quarter of the twentieth century, a process accelerated by the aftermath of the 2008 Global Financial Crisis. Nevertheless, as we suggested above, that settlement reflected longer-term continuities and many Europeans had absorbed and continued to hold its values. Large employers had come to see utility in parts of the social contract and incorporated elements into their everyday management practice. These continuities underlie the seismic changes in European labour markets and social attitudes that threaten it. They are reflected in other, more contingent, elements of the 'European model' as we show below in more detail.

Stakeholders. Many constitutions and legal systems in Europe, and certainly all those within the EU, give significant rights in businesses to a range of stakeholders (Beer, Boselie, \& Brewster, 2015 ) other than just the owners of the business. The firm is seen as a part of society as well as a private entity belonging to its owners. Groups seen to have a legitimate 'stake' in organisations therefore include employees, trade unions, customers, local and national governments and indeed society at large. All have a collective interest in the organisation, with 
regard to, for example, decisions about employment, the environment and business's role in society. In some countries, certain groups have a legal basis for influencing organisational decisions. For example, in the Germanic countries co-determination through works councils and trade unions is comparatively strong and legally regulated. The stakeholder concept has also been crucial to the EU's approach to social policy, as we detail below.

Role of the state. It has been argued that state regulation and the more limited autonomy of employers distinguish HRM, particularly employment relations, in Europe from those in the USA (Pieper, 1990: 82) and this remains an accurate assessment. Of course, the comparison could equally well be made with many other countries and regions besides the United States of America. In Europe, the state intervenes directly in the economy. National, regional and local governments either own or part-own larger parts of the economy and, overall, the state is therefore a more substantial employer (employing up to half the working population in Norway, for example). The state also provides more services than is common elsewhere: to employees to help them develop their skills, find work, and understand their rights; to employers to help them meet legal requirements; and to employers and trade unions to resolve their differences. It does so directly, through conciliation services, for example, to regulate industrial disputes. It also does so indirectly through support to employers via state-aided vocational training and labour market programmes, including retraining and job transition support, job creation schemes and efforts to help younger people and the long-term unemployed access the labour market across the EU. Employment practices, including for example, wages, working hours and holidays, are at least in part regulated by the state - as is, as we shall show, employee communication. These interventions are frequently on a very large scale, like the financial subventions made by the German state in supporting the extent and quality of vocational education and training (Croucher and Brookes 2009).

Taken together the stakeholder approach and the role of government ensure a more comprehensive approach to education, social welfare, and health, for example, than is found in many other regions in the world. These 'background' factors influence voice and participation in Europe fundamentally. They mean that in general people are educated enough to have valuable opinions and confident enough not be frightened of speaking up.

Rights to and in a job. In Europe, the state generally accepts and guarantees individual's rights to and in their jobs. Pieper (1990), making this point, included the greater regulation of recruitment and dismissal, the formalisation of educational certification and the quasi-legal characteristics of the industrial relations framework in comparison to the USA. We could also 
include, or specify, legislative requirements on pay, on hours of work, on forms of employment contract, rights to trade union representation, requirements to establish and operate consultation or co-determination arrangements - and a plethora of other legal requirements. We might also include the more common legislation on equality or health and safety, which impact the employment relationship on both sides of the Atlantic. In addition, the state has historically provided better-developed welfare provision in European countries than elsewhere, underpinning a greater sense of employee income security. Although these arrangements are becoming less generous in international comparative terms, they remain distinctive, especially when compared to those in, for instance, most of Asia.

There have been significant and even dramatic changes to these arrangements in many European countries since the Global Financial Crisis. The most obvious example is that of Greece, although there have considerable changes to labour markets in many other countries particularly in the Mediterranean. In the extreme case of Greece the impact of the Crisis and the associated legislative and workplace changes has been severe. Considerable changes to the law have facilitated the imposition of part-time contracts of employment, the decentralisation of bargaining from industry level together with pay decreases (Eurwork 2013). Further, alongside reductions in numbers employed, an increase in work pressures and growing negative effects on health, many of these changes appear to becoming 'institutionalised' so that improvements in the economic situation will not reverse them. Nevertheless, strong elements of stability remain in much of the rest of Europe. The European model may be subject to erosion, but it remains important background to employee voice and its exercise at work, a subject we turn to next. We begin with trade unionism, as Europe historically has globally been its main redoubt.

\section{Forms of voice}

Voice generally, as readers of the book will be well aware, takes many forms however we examine four that show distinctive factors.

Legally-supported collective voice (1) Trade unions. It is often claimed that collective representation has become increasingly irrelevant to current workplace realities given employee individualisation and the active promotion of neo-liberal models, particularly since the Global Financial Crisis that began in 2008. Yet this argument has recently been convincingly challenged as inadequately reflecting their continued importance to worker voice 
in Europe and more widely (Meardi, 2014). Collective bargaining results are extended well beyond those directly concerned, through the industry-wide bargains common in many European countries; France provides the most extreme example as nine out of ten workers are covered by them even though nine out of ten are not union members. Perhaps even more importantly, collective forms of voice provide workers raising concerns with a degree of protection from hostile management reacting to them as individuals. Trade unions are one of the two main forms of collective employee representation in Europe, along with 'codetermination' or the system of ensuring that all employees voices are heard both at workplace through works councils and in some countries at the strategic company Supervisory Board level. Here, we deal with trade unions.

Europe has more people in free trade unions than other regions of the world. This is a highly unionised continent. Union memberships range from almost everyone in some of the Nordic countries to almost no-one in France and some of the ex-communist countries. Thus, there is great diversity in levels of union membership in different countries but there is no direct correlation between the levels of membership and employee representative influence. To make one comparison: although German unions are widely and indeed correctly thought of as powerful, their overall density level among economically active employees (at 17.7\%: 2013) is rather lower than in Britain (25.4\%: 2013) where they are often thought of as relatively weak (EIRO, 2015). A key determinant of union influence is the level of support for trade unionism provided in national legal frameworks and this is much stronger in France, Belgium, the Netherlands, Germany and the Nordic countries than in Britain (Charlwood, 2006). Even in France the fragmented unions have a significant influence on employment issues, wages and working conditions. The central reason for French union influence is the Republican tradition, which has long encouraged constant negotiation between the state and society, now including 'social partners', that crosses political parties. Britain has neither strong legal foundations for trade unions nor entrenched state traditions supporting them.

'Trade union', even in Europe, is a single term that covers many different forms of organisation with varying implications for employee voice. Although many commentators operate with a West European default model of trade unionism, ie of a body seeking to develop self-activity and voice among workers themselves in order to bargain collectively, this is quite different from the model assumed by many workers in Eastern Europe where a more instrumental attitude and welfare-based attitude exists. We examine first the West European situation. Where works councils and other forms of employee representation are often used by managers 
in different countries in pragmatic ways, to supplement less formal communication channels on certain issues where they need to strengthen employee 'buy-in' to their initiatives; this practice has been shown to remain common in Europe's larger companies (Brewster et al, 2007). The opportunistic use of collective representation by managers demonstrates that there is a degree of utility to them in that a single representation channel is useful to employers, challenging the supposedly 'universal best practice' individual voice models suggested by some commentators (Brewster et al, 2007). Further, it seems that higher levels of trade unionism are associated with a more strategic approach to HRM by employers (Vernon and Brewster, 2012).

There has been considerable deterioration in the density and quality of workplace representation in many Western countries since the 1970s, particularly since the Global Financial Crisis. Britain is an extreme case in this respect, with workplace representation through shop stewards declining markedly in its incidence and quality across the period (Arrowsmith \& Pulignano, 2013). The 'big picture' is that trade unions across Europe have been in a period of decline over the last thirty years that has been uneven across nations but is nevertheless visible in most EU countries. The unevenness is very evident: in a few cases, such as in Malta, membership has increased (EIRO 2016). But in others, the Nordic countries continue to exhibit well-established voice and co-determination mechanisms. However, in the UK, France and Germany there has been a steady decline, while in Southern Europe it has been a steep decline, especially since the financial crisis (EIRO 2016). This trend cannot simply be equated to a decline in collective voice; indeed it has stimulated other forms of collective voice such as employee networks. An example has been the Siemens employee network, which grew in the company not in opposition to but rather in symbiosis with the trade union and works council. The employee network took large-scale demonstrative and legal action against the company with some success (Croucher et al, 2007).

In those countries which entered the European Union as post-communist 'accession countries' between 2007 and 2013 and also in the countries bordering them - Belarus, Ukraine and Moldova - very different systems existed immediately after 1989. In all of them, the Communist legacy and arguably longer-term social factors continue to play a role in workers' mentalities. Trade unionism was and to some extent still is considered as a way of administering welfare to workers; it is considered less a means for informing, mobilising and supporting workers in seeking to exercise voice than as operating on behalf of management. Majority 'official' (government-approved) unions therefore still live with this legacy of not 
offering workers voice but rather providing them with benefits. Unions deal with this legacy in different ways: many have made serious efforts to move away from the communist model of unions and to take on more of a bargaining role. A small group of 'independent' unions exists in some countries, but these remained an embattled minority restricted to a few industries; they have offered more participation to members and always had a more democratic ethos but also limited membership. Through their national-level federations the mainstream official unions have long been involved in tripartite arrangements which Ost (2000) characterised as 'illusory corporatism' which integrated the unions into government without offering real democratic opportunities. Meardi (2007) largely confirmed this verdict just before the Global Financial Crisis, pointing to a weakening in countries where trade unionism had previously been more effective. Negotiation at all levels is often simply formal and tokenistic. However, in these 'accession countries', links have long existed with western unions through training programmes and therefore, although still stamped by their history, they have gradually reformed, taking on more democratic procedures and much of the bargaining role of their Western counterparts (Croucher \& Rizov, 2012). Contrary to many western perceptions, studies show that Central and Eastern European unions in the ex-communist countries there are capable of exercising some influence in companies, particularly in large public sector organisations and when the business cycle is in a downturn (Croucher \& Rizov, 2012). Nevertheless, workers remain comparatively weak in the employment relationship in relation to their western counterparts and unhappiness with local employers has increasingly taken exit, i.e. migration, routes. This has in turn strengthened the hand of those who remain by creating labour shortages (Meardi, 2007). Nevertheless, examples of collective action by workers, although limited, were increasing prior to the onset of the financial crisis (Meardi, 2007).

A contrast exists between these countries and those to their immediate East, since the possibilities there both for exit and collective employee voice are less. Workers in the former Soviet Union states (FSUs) certainly have few voice options. Even before Ukraine was devastated and its trade unions divided by war, employers simply used many workplace-based unions as 'rubber stamps' for approving 'collective agreements' as required by law (Croucher, 2010). In Belarus, workers continue to express anger at their unions having become ineffective vehicles for expressing their views on issues of great importance to them (Danilovich et al 2015).In Moldova those unions previously showing some independence of government and an increasing capacity to involve workers and build their confidence to exercise voice at work have suffered from government hostility and have been marginalised while Communist-style 
welfare unions have been encouraged (Morrison \& Croucher, 2010). Thus, voice expectations between workers in Eastern and Western Europe remain very different, increasing the difficulty of building common European approaches.

Legally-supported collective voice (2) Co-determination. The most distinctive of the European contributions to voice is probably the existence of works councils. Works councils originated in Germany immediately after the revolutionary upsurge at the end of the First World War, were abolished by the Nazis and re-constituted again after 1945 as a significant aspect of democracy. They therefore have deep historical roots. Works councils carry out more day-today representation of employee interests and 'oil the wheels' of manager-worker interaction. They have rights to 'co-determine' certain important issues with management, and must be consulted or informed on a further range of matters (Singe \& Croucher, 2004). Their legal rights are also the basis for works councillors to conduct informal bargaining with managers. German works councils, or Betriebsräte, in common with the comités d'entreprises system in all larger French businesses, potentially provide a means for ensuring that employee voice is heard. The German approach has been the basis for providing employee voice in numerous other countries.

There are few detailed studies showing the system in action as a form of worker voice, but it is clear from these studies that there is very wide variation between workplaces in terms of how well the works council system operates. In his first classic study, Kotthoff (1981) identified six types of works council, three of which he regarded as effective in achieving worker voice and participation. A further study (1994) focused on links with wider democracy in Germany, but also revealed wide variation in works councillors' actual relations with managers. Ten years later, Singe and Croucher (2004) examined the system's detailed workings in two finance companies and found a sharp contrast between works council effectiveness in the two firms which was largely linked to the effectiveness of links with trade unions in the two workplaces. As a form of 'voice', the system is relatively effective compared to employer-driven consultative committees or individual voice, as works councillors have strong legal protection and workers in large companies are well aware of their value (Singe \& Croucher, 2004).

Despite declining collective bargaining coverage, trade unions in many European countries, including France and Germany, continue to bargain over pay and conditions at industry level, thereby externalising conflict on these issues beyond the workplace and permitting the development of a co-operative atmosphere at workplace level through co-determination. Unions also provide training and informational support to works councils which can improve 
their effectiveness (Croucher \& Singe, 2004). Despite concerns that work councils might act as substitutes for trade unions, it is clear that trade unions and works councils supplement each other (Brewster, et al., 2007). Strong unions are extremely positive for the main form of collective employee voice which complements trade unionism: works councils.

The co-determination system, once an unquestioned fact of industrial life in many European countries, has increasingly been debated, particularly in its board-level dimension. This is a widespread practice in European countries both inside and outside the EU and indeed is required in firms registered as 'European' companies recognised under the EU's 2001 European Company Statute. It is a system of worker representation on boards, often applying to larger companies and in some countries extending to smaller firms. It does not exist in the UK, although that country's Trades Union Congress currently advocates its extension to companies there. In some countries co-determination permits some inputs into company strategy, in others such as the Francophone and Nordic countries, worker representatives have a more restricted role both de jure and in practice and have less input into strategy (Waddington \& Conchon, 2015).

Some aspects of these arrangements have been challenged by employers. The German employers' association, the BDA, has been critical of its alleged hampering of German employers' capacity to compete internationally. As a result, earlier demands that the system of equal numbers of worker and other directors operated in mining and heavy industry be extended more widely have receded. Recent comprehensive survey research across sixteen European countries and a sample of European companies conducted for the European Trade Union Institute shows that on occasions these directors can achieve a significant role in board debates, ensuring that employee views are more salient there than they might otherwise be, although in others this is less apparent (Waddington \& Conchon, 2015). These researchers find that a key consideration in the effectiveness of these worker board members is how well linked they are to other systems of worker representation.

Beneath the large company level, in smaller companies and in many workplaces in the German Mittelstand, or smaller and medium-sized enterprises, a sizeable 'co-determination free zone' has developed and in this large group of organisations employees have no formal collective voice mechanisms with any degree of independence from the employer. They therefore have only weaker forms of voice to fall back on: employer-driven forms and the possibility of exercising voice in an individualised and in that sense unprotected way. We deal with the former immediately below and then turn to individual voice in the following section. 
Employer-driven collective voice. From the mid-1990s onwards, these forms of employee voice, typically known by names such as 'company councils' or 'non-union joint consultative committees' (although less widespread than those that are legally-supported) became more common, especially in the UK and parts of Eastern Europe. There has been little research on them and very little on their effectiveness. Case study research provides some potential explanation for why such initiatives have been limited in the UK. Upchurch and his colleagues document a 'paradox of intention': that employers seek to gain from employee involvement while structural limits, inter alia a wish to avoid unionisation, restrict what can be achieved (Upchurch et al, 2006). Secondly, other work shows that these forms of representation can have some utility for employees, including those in unionised situations but also that rather than displacing a need for union representation it has a complementary effect (Gollan, 2006), thus showing in this detailed case study a similar effect to that found by Brewster et al (2007) across Europe. This research was carried out at Eurotunnel (UK), which instituted non-union representation prior to acquiring union representation later and studied its workings across a five-year period. The Company Council had an informational and consultative role, and also managed a social welfare budget. Initially, the Council also had a collective bargaining role, although this function later passed to the trade union. These particular circumstances allowed the Company Council to establish itself prior to unionisation. Although support for the Company Council among employees, as reflected in surveys, declined over the five year period, and the union increased its membership, overall employees felt that the two bodies were complementary.

In some Eastern European countries outside of the EU, such as the Ukraine, some employers have also pursued a strategy of seeking to build non-union forms of voice as an alternative to existing workplace unions, which continue to have a certain legal role. They have created (in local parlance) 'yellow unions', using them as channels for welfare distribution and approval of legally-required 'collective agreements' (Croucher, 2010).

Individual voice. The use of individual voice, in various forms, is almost ubiquitous across Europe (Brewster et al, 2014). However, we are unaware of any comprehensive survey allowing us to estimate its effectiveness with any pretensions to accuracy. The 'direct' expression of employee voice, unmediated by representatives, is a preference of US-style HRM. It is encouraged by the international neo-liberal consensus and has increasingly appeared preferable to many European managers. Managers' calculation has increasingly been that the costs of collective voice outweigh the benefits, although this is more the case in some countries 
and industries than in others (Willman et al, 2006). These costs - and especially the high startup costs associated with collective employee voice - may well deter employers in small and medium-sized enterprises, such as those common in Mediterranean countries but also famously important in Germany, from instituting these measures. Managers also suggest that there is a lack of interest from employees in the more formalised, collective and 'indirect' forms of voice. This may be the case among some types of employee in strong labour market positions and without strong occupational traditions of representation (Willman et al, 2006)). However, many employee surveys continue to show a demand for some or improved representation beyond what they currently experience. We therefore follow Willman et al (2006) in preferring an explanation of the increasing emphasis on such forms as a result of management choice, while recognising that worker attitudes play some role (Charlwood, 2006).

Contrary to theories postulating convergence of practice in European firms towards a US-style model of individual voice, research provides little or no support for the 'convergence' argument, at least in larger firms. And the paternalistic individualism in smaller, particularly family-managed, firms that is widespread across Europe is very different from the 'US-style HRM stereotype. Research examining firm-level practice in Britain, Germany and Sweden before the financial crisis demonstrated that managers continued to make substantial use of collective voice mechanisms of all kinds. There was only very limited evidence of directional convergence towards individual voice in any of the major industrial countries examined (Brewster et al, 2007).

In some companies with relatively flat hierarchies, such as in many small companies in the digital economy, individual voice may be more frequent and effective than in more hierarchical or lower trust environments. This is particularly likely to be the case where workers have specific skills that are in high demand. However, the pervasive increasing weakness of employees in the employment relationship across all European industries has become increasingly evident and hints that employees are likely to feel less confident about raising concerns than they were previously. The experience of many 'whistleblowers' appears to bear this out. 'Whistleblowing' refers to individuals raising issues about unethical, unfair or illegal corporate or organisational practices, and is one, albeit very specific, form of individual voice (see chapter $\mathrm{X}$ in this book). It is one that seems clearly in the public interest and therefore desirable in principle. The issues raised may include matters of interest to employees, but also encompass subjects such as fraud and corruption. The adequate protection of whistleblowers is therefore a matter of good corporate governance (Lewis \& Vandekerckhove, 2011). Legally- 
backed 'whistleblowing' procedures exist in 29 countries around the world and are not exclusive to Europe, although many European countries have them (Lewis \& Vandekerckhove, 2011). Yet experts on whistleblowing from Norway, where employment protection is strong even in European terms, suggest that some whistleblowers, and even people contemplating it or associated in some way with the whistleblower, experience retaliation and bullying. The experts therefore recommend stronger legislation to deal with the issue (Bjørkelo \& Mathiesen, 2011).

\section{The EU, legislation and social dialogue: history, development, controversy}

As we outlined in the introduction, a distinctive aspect of Europe as a regional bloc has long been the idea that such a bloc required trans-national institutions for worker voice. A key European innovation was the development of European works councils (EWCs). There had long been recognition of the need for firm-level organs that would inform and consult workforces on a European scale. Some companies had indeed adopted such institutions voluntarily, and there was increasing demand for European regulation. The result was the 1994 EWC Directive. This directive stipulated that EWCs were to be established in undertakings with 'at least 1,000 employees within the Member States and at least 150 employees in each of at least two Member States', and set out voluntary and prescribed modes of compliance with the directive. Providing they covered the entire European workforce, 'article 13' EWCs established prior to 22 September 1996 needed not comply with the directive's terms. Those EWCs set up after this date, known as 'article 6' EWCs, were obliged to follow a model set out by the directive.

The proliferation of EWCs has inspired a large literature. Though some accounts focused on the weakness of such institutions in comparison to national works councils (Streeck, 1997), and the lack of interest shown by companies based in the UK, others were more sanguine and emphasized the innovativeness of EWCs and their capacity to develop (Ramsay, 1997). German unions insisted that EWCs did not represent co-determination vehicles, but were simply consultative bodies. The directive itself was also subject to revision precisely because some were critical of its limitations. Following years of trade union lobbying for fortification of its terms, a 2009 revision more clearly demarcated divisions of labour between EWCs and national works councils, better defined the rights of EWCs to information and consultation and gave more influence to trade unions. A European Company Statute (ECS) is also now available, giving such companies certain legal and fiscal rights but requiring further consultation. 
Following adoption by the EU's Employment and Social Policy Council in 2001, the ECS required employee involvement through board-level participation and 'representative bod[ies]'. Though such rights were not revolutionary, they were nonetheless an important supplement to existing forms of employee representation (Gold \& Schwimbersky, 2008).

European regulation also strengthened information and consultation rights at member state level. Following concern that existing arrangements in certain countries were insufficient, the 2002 Information and Consultation Directive stipulated that institutions for the information and consultation of employees be established in 'undertakings employing at least 50 employees in any one Member State, or establishments employing at least 20 employees in any one Member State'. Nine sequential stages for the information and consultation of employees, from the transmission of data to discussion 'with a view to reaching an agreement on decisions', were set out. The directive was criticised, as sceptics pointed to its weak terms and the preexistence of stronger institutions in several member states (Koukiadaki, 2010; Hall \& Purcell, 2011). Nevertheless, it at least established works councils in countries without such institutions, arguably a major permissive contribution to social dialogue at national level.

Social dialogue has also become established at European-level in recent decades. As part of the first Delors Commission's attempts to combat social dumping, summits between representatives of European labour and business were organized from 1985. The results of the so-called Val Duchesse dialogue, a name inspired by the Brussels château in which meetings were held, were nonetheless non-legally binding and tended to concern topics at the margin of the employment relationship. European-level social dialogue was strengthened in the early 1990s. The Social Protocol, annexed to the Maastricht Treaty in 1992 as a result of the UK Conservative Government's opposition, set out procedures for the conclusion of legally binding and non-legally binding European collective agreements. In the years following the Social Protocol three agreements, on Parental leave (1995), Part-time work (1997) and Fixedterm work (1999), were implemented via legally binding Council Directives. Many were optimistic about these developments. A series of authorities underlined the dialogue's procedural and substantive achievements and potential to develop, and the onset of Eurocorporatism was even heralded (Falkner, 1998; Welz, 2008).

Others were sceptical. These authorities pointed to the exclusion of crucial competences such as pay from the dialogue's scope, the organizational weakness of the European social partners and the dialogue's dependence on the European Commission. Developments after 2000 appeared to vindicate the sceptics. In response to the EU's impending enlargement and the 
increasing popularity of non-legally binding 'soft' European governance methods such as the Open Method of Coordination (OMC), the dialogue assumed a 'softer' form. It became known as the 'new phase' (Prosser, 2006). Agreements concluded during the 'new phase' were implemented via the non-legally binding implementation route outlined in the Social Protocol. The Telework Agreement (2002), Work-related Stress Agreement (2004), Harassment and Violence at Work Agreement (2007) and Inclusive Labour Markets Agreement (2010) were all implemented via the "procedures and practices specific to management and labour in the member states', and therefore depended on national social partners for implementation. Potential problems with this implementation route were soon foreseen (Keller, 2003). Social dialogue structures in several member states were uncoordinated and/or fragmented, and studies of implementation outcomes typically arrived at pessimistic conclusions (Larsen \& Andersen, 2007; Prosser, 2011).

Attempts at European sectoral-level social dialogue suffered from similar problems. Though the 1998 launch of European sectoral social dialogue committees (SSDCs) inspired the creation of a number of such institutions, the output of SSDCs was rather disappointing (Prosser \& Perin, 2015). Agreements subsequently implemented by Council Directive were concluded in certain sectors in which there were integrated markets and Europeanised sectoral policies (Leisink, 2002), but in most sectors these outcomes were absent. Many SSDCs contented themselves with the production of non-legally binding texts aimed at the European public authorities, and it was argued that they functioned primarily as lobbying forums (De Boer et al, 2005).

A variety of policies and institutions that guarantee the European-level participation of employees thus exist. Though they have been the subject of criticism, such forums for the transnational consultation of employees are unique and can point to numerous achievements. These institutions will therefore continue to function, although will evolve to meet the challenges and the power relationships of the twenty-first century.

A particular challenge will be the decision of the UK to leave the EU. Though it has been suggested that the exit of the traditionally neoliberal UK might allow remaining member states to strengthen legislation guaranteeing European-level employee participation, it is difficult to see such a scenario materializing in the short-term. Not only is the attention of the EU fixed on the resolution of a series of existential challenges, but considerable opposition to the fortification of such regulation exists in other quarters. Implications for employee participation in the post-Brexit UK are also intriguing. Even if certain figures in the governing Conservative 
party favour the repeal of European regulation in this area, the apparent desire of the May Government to guarantee employee protection, not to mention logistical challenges associated with the abolition of such legislation, make this eventuality improbable.

Comparative capitalisms and voice. Attempts have been made to apply wider analyses of corporate governance systems within different varieties of capitalism to explain the variations in employee voice across Europe. The comparative capitalisms literature (Jackson \& Deeg, 2008) draws distinctions between the ways that capitalism works in different contexts. Typical categories include the Anglo-Saxon liberal market economies (LMEs) and the co-ordinated market economies of Rhineland Europe (Hall \& Soskice, 2010). It is argued that the former are characterised by competition, a requirement enshrined in law, a lesser role for government and hence lower taxation and limited state provision of welfare benefits and health. The latter are characterised by greater coordination between firms, more involvement of government with firms, and better welfare provision. These differences go through into the relationships between employers and employees with higher degrees of interdependence and delegation (Whitley, 1999) in CMEs. Higher interdependence means that people stay longer with the same firm, therefore training and development make more sense to both parties and voice becomes more important. Higher delegation means that people are trusted more, and have greater participation in their work and their firm. We have seen some of these factors at work in our discussions of Germany and the Netherlands versus the UK and Ireland.

There are multi-category versions of the comparative capitalisms theories. Thus, Amable (2003) identified within Europe social democratic capitalism, in the Nordic countries, Mediterranean capitalism and the emerging economies of central and eastern Europe. Again, we have seen how these contextual factors influence employee voice: the Nordic countries have much higher levels of trade union membership, including trade union membership for many managers, excellent social security, government support for, for example, retraining and there is an expectation (little legislation is required) that people will be consulted about their work and their voice will be heard in the organisation they work in. The Mediterranean countries, characterised by a split between high levels of small, often family-run, businesses and a more rule-bound public and large firms sector, have low levels of trade union membership, poor social security and paternalistic human resource management. Independent employee voice is limited. We have discussed the vast range of practices developing in the, often institutionally weak, former communist states and former Soviet Union states.

Test of internal relationships and voice (Brewster et al, 2014, 2015; Brookes et al, 2016) seem 
to show support for these different categories and help to explain why they exist. The comparative capitalisms literature has, like much of the institutional and regulation literature been criticised because although it provides a much better understanding of how firms (and unions, etc) are embedded in their context, it struggles to cope with change - if everything is embedded in a series of complementarities and path-dependent, then how do things change? The literature is attempting to respond to this critique. Thus, Amable and Palombarini (2009) emphasised the importance of power and politics in the development of systems and Streeck (2010), following the same ideas, has argued that pressures from the LMEs are causing the CMEs to move towards them, weakening the institutional complementarities. Nuanced accounts by Thelen $(2009,2014)$ attempt to unpick the detail of changes within specified countries, and foreign private equity does seem to have an impact on changing individual organisations towards patterns which include less voice (Guery et al, 2016). However, although there is inevitably change, the evidence (Mayrhofer et al., 2011) seems to be that human resource management practices, including employee voice, still remain distinct in each variety of capitalism.

\section{Summary and conclusions}

There is no area of employee voice in which Europe is unique, except obviously its history and the influence of the European Union. In all other areas, even the use of works councils and the strength of the legislation requiring employers to allow and respond to employee voice, there are other examples around the world - most of them, of course, heavily influenced by the example of Europe. But the combination of still strong trade unions, legislative support, a belief in stakeholders' rights, powerful institutional demands and continent-wide, multi-country legislation is unique. And it creates a unique environment for employee voice. The general right-wing shift amongst European governments and the increasing acceptance of the neoliberal logic place this legacy at risk. It will be worth paying close attention to developments in voice in Europe over the next few years. 


\section{References}

Amable, B. (2003). The Diversity of Modern Capitalism. Oxford: Oxford University Press

Amable, B. and Palombarini, S. (2009). A Neorealist Approach to Institutional Change and the Diversity of Capitalism.” Socio-Economic Review7 (1): 123-43.

Arrowsmith, J. and Pulignano, V. (2013). The Transformation of Employment Relations in Europe. London: Routledge.

Beer, M. Boselie, P. and Brewster, C. (2015). Back to the future: Implications for the field of HRM of the multi-stakeholder perspective proposed 30 years ago. Human Resource Management 54 (3): 427-438

Bjørkelo, B. and Mathiesen, B.S. (2011). Preventing and dealing with retaliation against whistleblowers, in Whistleblowing and Democratic Values, Vandekerckhove, W., Lewis, D. (eds.). London: International Whistleblowing Research Network: 127-149.

Brewster, C., Brookes, M., Croucher, R. and Wood, G.T. (2007). Collective and individual voice: convergence in Europe? International Journal of Human Resource Management. 18 (7): $1246-1262$

Brewster, C., Brookes, M., Johnson, P. and Wood, G. T. (2014). Direct involvement, partnership and setting: a study in bounded diversity International Journal of Human Resource Management, 25(6): 795-809

Brewster, C., Wood, G.T., Croucher, C. and Brookes, M., (2007). Are Works Councils and Joint Consultative Committees a threat to trade unions? A comparative analysis, Economic and Industrial Democracy. 28 (1): 53-81

Brewster, C., Wood, G.T. and Goergen, M. (2015). Institutions, unionization and voice: The relative impact of context and actors on firm level practice Economic and Industrial Democracy 36 (2): 195-214

Charlwood, A. (2006). What determined employer voice choices in Britain in the $20^{\text {th }}$ century? A critique of the 'sound of silence' model. Socio-Economic Review 4: 301-309.

Croucher, R. (2010). Employee involvement in Ukraine. International Journal of Human Resource Management, 21 (14): 2659-2676. 
Croucher, R. (2016). Employment relations in Europe. In: International Human Resource Management: contemporary human resource issues in Europe. Dickmann, M., and Brewster, C., and Sparrow, P., eds. Routledge: 262-281.

Croucher, R., Martens, H. and Singe, I. (2007). A German employee network and union renewal: the Siemenskonflikt. Industrial Relations/ Relations Industrielles, 62 (1): 143-169.

Croucher, R. and Brookes, M. (2009). German employers' inputs to vocational education and training. Industrial Relations: A Journal of Economy and Society 48 (2): 231-6.

Croucher, R. and Miles, L. (2009). The legal structuring of women's collective voice in the South Korean workplace. Journal of Contemporary Asia, 39 (2):231-246.

Croucher, R., Rizov , M. (2012). Union influence in Eastern Europe ILR Review. 65 (3): 630650

Danilovich, H., Croucher, R. and Makovskaya, N (2015). Compulsory reduced working time in Belarus: Incidence, operation and consequences. Economic and Industrial Democracy. $0143831 X 15586071$.

De Boer, R., Benedictus, H. and Van Der Meer, M. (2005). Broadening without intensification: the added value of the European social and sectoral dialogue. European Journal of Industrial Relations 11(1): 51-70.

Eurwork (2013). Greece: Impact of the Crisis on Industrial Relations. Dublin: European Foundation. Accessed 16 February, 2016.

Falkner, G. (1998). EU Social Policy in the 1990s: Towards a Corporatist Policy Community. London: Routledge.

Guery, L., Stevenot, A., Wood, G. and Brewster, C. (2017) The impact of Private Equity on employment: the consequences of fund country of origin - new evidence from France Industrial Relations: a journal of economy and society 56 (4): 723-750

Gold, M. and Schwimbersky, S. (2008). The European Company Statute: implications for industrial relations in the European Union, European Journal of Industrial Relations 14(1): 4664.

Gollan, P.J. (2006). A process of transition - employer strategies and outcomes of employee voice at Eurotunnel, Socio-Economic Review 4: 337-351. 
Kotthoff, H. (1981). Betriebsräte und betriebliche Herrschaft. Eine Typologie von Partizipationsmustern im Industriebetrieb. Campus, Frankfurt am Main.

Gooderham, P., Navreberg, S.E., Olsen, K.M. and Steen, C.R. (2014). The labour market regimes of Denmark and Norway - one Nordic model? Journal of Industrial Relations 57 (2): 166-86.

Hall, M. and Purcell, J. (2011). Information and Consultation Practice across Europe Five Years after the EU Directive. Dublin: European Foundation for the Improvement of Living and Working Conditions.

Hall, P., \& Soskice, D. (2001). Varieties of Capitalism: the Institutional Foundations of Comparative Advantage. New York: Oxford University Press.

Jackson, G., \& Deeg, R. (2008). Comparing capitalisms: understanding institutional diversity and its implications for international business. Journal of International Business Studies, 39(4), 540-561.

Keller, B. (2003). Social dialogues: the state of the art a decade after Maastricht. Industrial Relations Journal 34(5): 411-29.

Kotthoff, H. (1994). Betriebsräte und Bürgerstatus. Wandel und Kontinuität betrieblicher Mitbestimmung. Hampp, München.

Koukiadaki, A. (2010). The establishment and operation of information and consultation of employees' arrangements in a capability-based framework, Economic and Industrial Democracy, 31(3): 365-388.

Larsen, T. and Andersen, S. (2007). Autonomous Framework Agreements: A new way of regulating Europe. European Journal of Industrial Relations 13(2): 181-198.

Leisink, P. (2002). The European sectoral dialogue and the graphical industry. European Journal of Industrial Relations 8(1): 101-117.

Lewis, D., Vandekerckhove, W., (2011). Introduction in Whistleblowing and Democratic Values, Vandekerckhove, W. and Lewis, D. (eds.). London: International Whistleblowing Research Network

Mayrhofer, W., Brewster, C., Morley, M. and Ledolter, J. (2011) Hearing a Different drummer? Evidence of convergence in European HRM Human Resource Management Review 21 (1): 5067 
Mayrhofer, W., Sparrow, P.S. and Brewster, C. (2012). European human resource management: a contextualised stakeholder perspective (Chapter 23) in Brewster, C. and Mayrhofer, W., (eds) (2012). A Handbook of Research into Comparative Human Resource Management Practice. Edward Elgar, Cheltenham

Meardi, G. (2007). More voice after more exit? Unstable industrial relations in Central and Eastern Europe. Industrial Relations Journal 38(6): 503-23.

Meardi, G. (2014). The (claimed) growing irrelevance of employment relations Journal of Industrial Relations. 56 (4): 594-605.

Morrison, C., Croucher, R. (2010). Moldovan employment relations: path dependency? Employee Relations, 32 (3): 227-247.

Pieper, R. (1990). Human Resource Management: An International Comparison. Berlin: Walter de Gruyter.

Prosser, T. (2006). Is the "new phase' of the European Social Dialogue the development of an autonomous and effective form of social dialogue? Warwick Paper in Industrial Relations 82. Prosser, T. (2011). European social dialogue through 'soft' law? European Journal of Industrial Relations 17 (3): 245-260.

Prosser, T. J. and Perin, E. (2015). European tripartism: chimera or reality? The 'new phase' of the European social dialogue in the light of tripartite theory and practice. Business History 57(3), pp. 376-397.

Psychogios, A., Brewster, C., Kohont, A., Vatchkova, E. and Slavic, A. (2014). Industrial Relations in South East Europe: disaggregating the contexts International Journal of Human Resource Management 25 (11) 1592-1612

Ramsay, H. (1997). Fool's gold? European Works Councils and workplace democracy, Industrial Relations Journal 28(4): 314-322.

Singe, I. and Croucher, R. (2004). Co-determination and working time accounts in the German finance industry. Industrial Relations Journal, 35 (2): 153-168.

Streeck, W. (1997). Neither European nor Works Councils: a reply to Paul Knutsen, Economic and Industrial Democracy 18(2): 325-337.

Streeck, Wolfgang. 2010. E Pluribus Unum? Varieties and Commonalities of Capitalism. MPIfG Discussion Paper 10/12. Cologne 
Thelen, K. (2009). Institutional change in advanced political economies. British Journal of Industrial Relations, 47(3), 471-621.

Thelen, K. (2014). Varieties of Liberalization and the New Politics of Social Solidarity. Cambridge: Cambridge University Press.

Upchurch, M., Richardson, M., Tailby, S., Danford, A. and Stewart, P. (2006). Employee representation and partnership in the non-union sector: a paradox of intention? Human Resource Management Journal 16 (4): 393-410.

Upchurch, M., Croucher, R., Danilovich, H. and Morrison, C. (2015). The transformation of work and industrial relations in the post-Soviet bloc: 25 years on from 1989. Work, Employment and Society, 29 (3): 1-11.

Vernon, G. and Brewster, C. (2012). Structural spoilers or structural supports? Unionism and the strategic integration of HR functions. International Journal of Human Resource Management: 24, (6): 1113-1130

Waddington, J. and Conchon, A., (2015). Board-level Representation in Europe. Brussels, European Trade Union Institute.

Welz C (2008). The European Social Dialogue under Articles 138 and 139 of the EC Treaty: Actors, Processes, Outcomes. Alphen aan den Rijn: Kluwer Law International.

Western, B. (2000). Between Class and Market. Cambridge, Mass: Princeton University Press. Willman, P., Bryson, A., Gomez, R. (2006). The sound of silence: which employers choose no employee voice and why? Socio-Economic Review 4: 283-99.

Wood, G.T., Brewster, C., Brookes, M., Cunha y Campos, R. and Dibben, P. (2016 forthcoming) Institutional Legacies and Capabilities: Work Practices and Employment Relations in Portugal and Mozambique International Journal of Human Resource Management 